\title{
ANALISIS KEBUTUHAN AREAL PARKIR MOBIL BANDAR UDARA TJILIK RIWUT PALANGKA RAYA DENGAN METODE JICA
}

\author{
Nitta Rahayu \\ Jurusan/Program Studi Teknik Sipil, Fakultas Teknik, Universitas Palangka Raya \\ Jln. Hendrik Timang, Palangka Raya, e-mail: nittarahayu13@gmail.com \\ Robby \\ Jurusan/Program Studi Teknik Sipil, Fakultas Teknik, Universitas Palangka Raya \\ Jln. Hendrik Timang, Palangka Raya, e-mail: robbykalteng.rk@gmail.com

\section{Murniati} \\ Jurusan/Program Studi Teknik Sipil, Fakultas Teknik, Universitas Palangka Raya \\ Jln. Hendrik Timang, Palangka Raya, e-mail: murniatiunpar@yahoo.co.id
}

\begin{abstract}
Tjilik Riwut Airport is the largest airport in Central Kalimantan. The number of air passengers through Tjilik Riwut Airport in 2018 reached 1,025,590 passengers. That number increased by around 10 percent compared to last year in 2017 which was 934,002 passengers. Along with the increasing growth of passenger movement, further studies are needed to determine need and demand of parking areas provision. The aims of research was to analyze the needs of the car parking area of Tjilik Riwut Airport. The method used to obtain data by primary data and secondary data. Primary data were collected through field surveys with parking surveys and vehicle types surveys. Secondary data were taken from PT. Angkasa Pura II (Persero) KC Tjilik Riwut Airport in the form of an existing parking layout, the number of parking vehicle data, the number of departures and arrivals passengers, parking area and capacity (number of parking lots), then combined to analyzes parking needs using the JICA (Japan International Cooperation Agency) method. The results of the analysis obtained based on the calculation of parking requirements with the JICA method are $13,024 \mathrm{~m}^{2}$ and based on the results of research, a parking area of $4070 \mathrm{~m}^{2}$ is required. Based on the analysis of parking needs with the JICA method, an additional car parking area of $8734 \mathrm{~m}^{2}$ is required, and based on the results of research, the existing parking area can still meet the parking needs for current conditions.
\end{abstract}

Keywords: parking, car parking needs, tjilik riwut airport

\begin{abstract}
Abstrak: Bandar udara Tjilik Riwut adalah Bandar udara terbesar di Kalimantan Tengah. Jumlah penumpang Bandara Tjilik Riwut pada tahun 2018 mencapai 1.025.590 penumpang. Angka tersebut meningkat sekitar 10 persen dibanding tahun 2017 yakni 934.002 orang. Seiring dengan meningkatnya pertumbuhan pergerakan penumpang, maka diperlukan kajian lebih lanjut guna mengetahui kebutuhan dan permintaan terhadap penyediaan areal parkir. Tujuan penelitian adalah menganalisis kebutuhan areal parkir mobil Bandara Tjilik Riwut. Metode yang digunakan untuk memperoleh data berupa data primer dan data sekunder. Data primer diambil melalui survei lapangan berupa survei lahan parkir dan survei jenis/tipe kendaraan. Data sekunder diambil dari PT. Angkasa Pura II (Persero) KC Bandara Tjilik Riwut berupa layout eksisting parkir bandara, data jumlah kendaraan parkir, data jumlah keberangkatan dan kedatangan penumpang, dan luas lahan parkir dan kapasitasnya (jumlah petak parkir). Berdasarkan data yang diperoleh dianalisis kebutuhan parkir menggunakan metode JICA (Japan International Cooperation Agency). Hasil analisis yang diperoleh berdasarkan perhitungan kebutuhan parkir dengan metode JICA adalah sebesar $13.024 \mathrm{~m}^{2}$ dan berdasarkan hasil penelitian dibutuhkan luas areal parkir sebesar $4070 \mathrm{~m}^{2}$. Berdasarkan analisis kebutuhan parkir dengan metode JICA untuk areal parkir mobil diperlukan penambahan luasan areal parkir sebesar $8734 \mathrm{~m}^{2}$, dan berdasarkan hasil penelitian, areal parkir yang ada masih dapat memenuhi kebutuhan parkir untuk kondisi saat ini.
\end{abstract}

Kata kunci: parkir, kebutuhan parkir mobil, bandar udara tjilik riwut 


\section{PENDAHULUAN}

Bandar udara Tjilik Riwut adalah sektor transportasi udara terbesar di Kalimantan Tengah, yaitu berada di Kota Palangka Raya, Ibukota Provinsi Kalimantan Tengah. Sebelumnya, Bandar udara Tjilik Riwut yang lama memiliki luas $5.000 \mathrm{~m}^{2}$, setelah pembangunan terminal Bandar udara Tjilik Riwut yang baru diresmikan April 2019, luasnya ditingkatkan menjadi $29.000 \mathrm{~m}^{2}$ (PT Angkasa Pura II Persero). Dengan adanya terminal baru ini, diharapkan dapat meningkatkan pertumbuhan ekonomi di Kalimantan Tengah, karena pertumbuhan jumlah penumpang dan barang melalui sektor tranportasi udara juga meningkat pesat.

Berdasarkan data dari Dinas Perhubungan Komunikasi dan Informasi Provinsi Kalimantan Tengah, jumlah penumpang udara melalui Bandara Tjilik Riwut pada tahun 2018 mencapai 1.025 .590 penumpang. Angka tersebut meningkat sekitar 10 persen dibanding tahun lalu yakni 934.002 orang. Menurut BPS Provinsi Kalimantan Tengah (2019), kenaikan jumlah penumpang pada tahun ini terjadi pada arus kedatangan dan keberangkatan. Pada tahun 2018 Untuk pesawat berangkat mencapai 4.941, meningkat dari keberangkatan tahun 2017 yang mencapai 4.486 penerbangan. Seiring dengan pertumbuhan pergerakan penumpang, maka diperlukan pengembangan bandar udara yang terkoordinir antar semua pihak untuk meningkatkan kinerja bandara dan sistem transportasi.

Untuk memenuhi perannya, bandar udara perlu ditunjang dengan fasilitas dan pelayanan yang handal. Seiring dengan terus meningkatnya jumlah penumpang per tahun, kenaikan tersebut mengakibatkan tingginya kebutuhan akan ruang parkir yang tersedia apakah masih dapat menampung kendaraan atau memerlukan alternatif lain yang layak dipertimbangkan. Saat ini, banyak pelaku perjalanan memilih menggunakan kendaraan pribadi seperti sepeda motor dan mobil untuk transportasi menuju bandara. Banyaknya jumlah kendaraan ini memacu meningkatnya jumlah kendaraan yang masuk bandara dan menimbulkan masalah tidak hanya pada ruas jalan, tetapi terhadap kebutuhan ruang parkir. Oleh karena itu diperlukan perencanaan jangka panjang yang difokuskan pada perbaikan utama dari fasilitasfasilitas bandara dan kebijakan yang akan mempengaruhi kinerja terminal karena keterbatasan dalam tingkat-tingkat pelayanan terutama pada waktu puncak keberangkatan dan kedatangan penumpang pesawat di Bandar udara Tjilik Riwut.

Tempat parkir dan sistem pengaturan perparkiran adalah komponen penting dan tidak dapat dipisahkan dalam pelayanan sebuah fasilitas umum. Keberadaan sistem perparkiran yang baik akan mendukung fasilitas umum yang digunakan oleh banyak pihak. Sistem parkir yang baik mencerminkan kebaikan sistem yang lebih luas dalam fasilitas umum tersebut. Fasilitas areal parkir menjadi sangat penting dalam suatu ruang publik seperti areal bandara, karena pelayanan fasilitas parkir menjadi kesan pertama dan kesan terakhir bagi pengguna jasa bandara.

Berdasarkan uraian di atas, sangat penting untuk melakukan kajian lebih lanjut untuk mengetahui kebutuhan ruang parkir, sehingga pengguna kendaraan dapat masuk dan keluar areal parkir tanpa terhambat serta mempermudah pengguna kendaraan bermanuver saat keluar dan masuk ruang parkir di Bandar udara Tjilik Riwut.

\section{TINJAUAN PUSTAKA}

\section{Bandar udara}

Menurut Peraturan Menteri Perhubungan Nomor PM 39 Tahun 2019 tentang Tatanan Kebandarudaraan Nasional pada Pasal 1 Ayat 3, Bandar udara adalah kawasan di daratan dan/atau perairan dengan batas-batas tertentu yang digunakan sebagai tempat pesawat udara mendarat dan lepas landas, naik turun penumpang, bongkar muat barang dan tempat perpindahan intra dan antar moda transportasi, yang dilengkapi dengan fasilitas keselamatan dan keamanan penerbangan, serta fasilitas pokok dan fasilitas penunjang lainnya.

\section{Definisi parkir}

Menurut Departemen Perhubungan (1996), parkir adalah keadaan tidak bergerak suatu kendaraan yang bersifat sementara. Parkir dapat definisikan sebagai keadaan tidak bergerak suatu kendaraan yang tidak bersifat sementara.

Menurut Solikhin (2017), banyak ahli tansportasi memberikan definisi parkir, yaitu:

1. Semua kendaraan tidak mungkin bergerak terus, pada suatu saat ia harus berhenti untuk sementara waktu (menurunkan muatan) atau berhenti cukup lama yang disebut parkir. 
2. Parkir adalah menempatkan dengan memberhentikan kendaraan angkutan orang/ barang (bermotor/tidak bermotor) pada suatu tempat parkir dalam jangka waktu tertentu.

Berdasarkan dari definisi di atas maka dapat ditarik kesimpulan bahwa parkir adalah keadaan tidak bergerak, kendaraan bermotor/tidak bermotor, dalam jangka waktu tertentu yang lama maupun sebentar tergantung pada kepentingan pengemudinya.

\section{Kebutuhan ruang parkir}

Menurut Abubakar (1998), kebutuhan ruang parkir adalah jumlah tempat yang dibutuhkan untuk menampung kendaraan yang membutuhkan parkir berdasarkan fasilitas dan fungsi dari sebuah tata guna lahan.

\section{Metode penentuan kebutuhan parkir}

Menurut Tamin (2008), adapun metode untuk penentuan kebutuhan jumlah petak parkir dapat diketahui berdasarkan:

1. Metode berdasarkan kepemilikan kendaraan Metode ini mengasumsikan adanya hubungan antara luas lahan parkir dengan jumlah kendaraan yang tercatat di pusat kota. Semakin meningkat jumlah penduduk, maka kebutuhan lahan parkir akan semakin meningkat karena kepemilikan kendaraan meningkat.

2. Metode berdasarkan luas lantai bangunan Metode ini mengasumsikan bahwa kebutuhan lantai parkir sangat terkait dengan jumlah kegiatan yang dinyatakan dalam besaran luas lantai bangunan dimana kegiatan tersebut dilakukan, misalnya perbelanjaan, perkantoran, kampus, dan lain-lain.

3. Metode berdasarkan selisih terbesar antara kedatangan dan keberangkatan kendaraan.

Kebutuhan lahan parkir didapatkan dengan menghitung akumulasi terbesar pada suatu selang waktu pengamatan. Akumulasi parkir adalah jumlah kendaraan parkir di suatu tempat pada selang waktu tertentu, dimana jumlah kendaraan tidak akan pernah sama pada suatu tempat lainnya dari waktu ke waktu.

\section{Metode JICA (Japan International Cooperation Agency)}

Metode JICA adalah salah satu metode yang dapat digunakan sebagai dasar perencanaan dan perancangan fasilitas pada bandar udara. Dalam perencanaan fasilitas terminal termasuk areal parkir mobil terdapat dalam peraturan yang dibuat oleh JICA. Menurut JICA (1992), JICA merupakan sebuah organisasi internasional dari Jepang yang berorientasi memajukan kegiatannya di seputar pilar pendekatan berorientasi lapangan, keamanan manusia, dan peningkatan efektivitas, efisiensi, dan kecepatan. Beberapa negara di dunia telah bekerjasama dan mengadopsi metode JICA khususnya dalam bidang kebandarudaraan termasuk Indonesia. Berikut adalah diagram alir perhitungan kebutuhan areal parkir mobil berdasarkan metode JICA. 


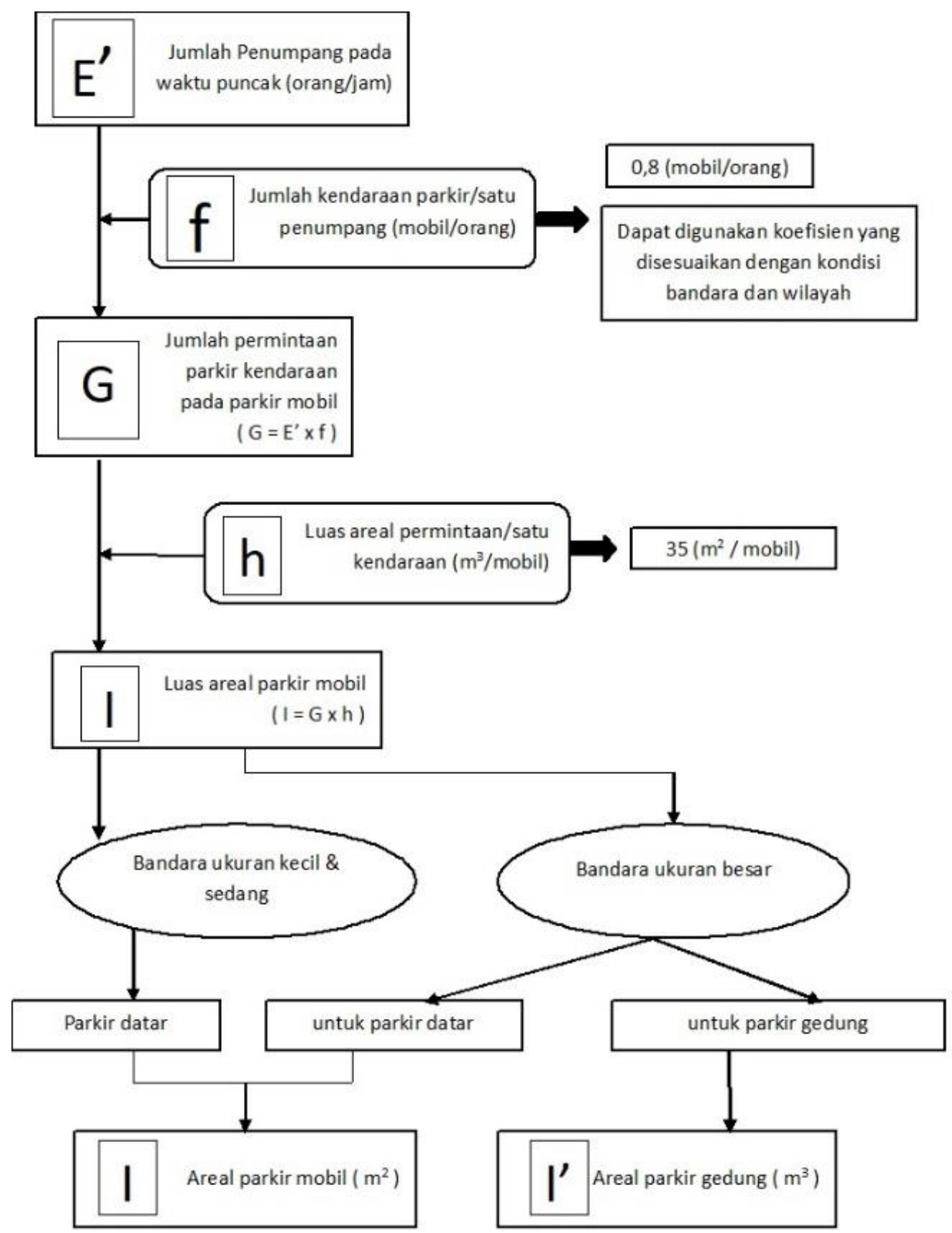

Gambar 1. Diagram alir perhitungan kebutuhan areal parkir metode JICA

Untuk menentukan areal parkir, luasnya berdasarkan banyaknya penumpang datang dan berangkat. Tempat parkir sedapat mungkin dekat dengan terminal / kawasan yang dilayani. Daya tampung dihitung dari jumlah penumpang waktu sibuk.

$$
\begin{aligned}
& G=E^{\prime} \times f \\
& I=G \times h
\end{aligned}
$$

Keterangan:

$\mathrm{E}^{\prime}=$ Jumlah penumpang jam sibuk, $\mathrm{f}=$ Jumlah kendaraan per penumpang $(0,8), \mathrm{G}=$ Jumlah kendaraan yang parkir, $\mathrm{I}=$ Luas lahan parkir dan $\mathrm{h}=$ Kebutuhan lahan parkir/kendaraan $\left(35 \mathrm{~m}^{2}\right)$.

\section{Penelitian terdahulu}

Menurut penelitian Saputra (2017), meneliti tentang "Analisa Kebutuhan Ruang Parkir di Bandar udara Raja Haji Fisabilillah Tanjung Pinang 
Kepulauan Riau”. Berdasarkan analisis perhitungan kebutuhan parkir yang sudah dilakukan maka dapat disimpulkan bahwa kebutuhan ruang parkir kendaraan roda empat dan kendaraan roda dua pada Bandara Raja Haji Fisabilillah masih dapat menampung permintaan.

Menurut penelitian Putri (2017), meneliti tentang "Analisis Karakteristik dan Kebutuhan Parkir di Bandara Internasional I Gusti Ngurah Rai Bali". Berdasarkan analisis perhitungan kebutuhan parkir yang sudah dilakukan maka dapat disimpulkan bahwa Bandara Internasional I Gusti Ngurah Rai pada saat ini masih memerlukan petak parkir untuk memenuhi kebutuhan parkir mereka. Kebutuhan parkir berdasarkan karakteristik parkir untuk jenis kendaraan roda 2 terdapat kekurangan sebesar 3.092 SRP. Untuk jenis kendaraan roda 4 kebutuhan ruang parkir adalah sebesar 1.897 SRP, sedangkan untuk jenis kendaraan roda 6 sebesar 42 SRP.

Menurut penelitian Prasetiyo (2014), meneliti tentang "Analisis Kebutuhan Ruang Parkir pada Kawasan Pusat Perdagangan Kota Tomohon" Berdasarkan hasil analisis dari data yang didapat selama penelitian didapat jumlah rata-rata kendaraan yang masuk area parkir selama kurun waktu seminggu adalah sebanyak 436 unit minibus, 4 unit bus/truck, dan 425 sepeda motor. Dari hasil analisis kebutuhan kapasitas parkir sendiri diperoleh bahwa area parkir on street pada kawasan pusat perdagangan Kota Tomohon sudah tidak lagi mencukupi yakni dengan SRP eksisting untuk mobil 53 unit dengan kebutuhan sebenarnya 56 unit, selain itu pada jam-jam puncak pada pukul 15.00 hingga 18.00 area parkir sudah tidak dapat menampung kendaraan yang datang sehingga sebagian kendaraan sulit untuk mendapatkan lokasi parkir.

Menurut penelitian Malik (2017), meneliti tentang "Analisis Kebutuhan Pelataran Parkir Kendaraan di Bandara Husein Sastranegara Bandung untuk Optimalisasi Ruang Parkir Kendaraan". Hasil analisis penelitian yang didapatkan yaitu pada tahun 2025 perkiraan jumlah roda empat mencapai
1.046.267 dan untuk roda dua adalah 225.596 dan untuk kebutuhan kapasitas parkir roda empat pada tahun 2025 adalah 422 SRP dan untuk roda dua adalah 712 SRP. Kebutuhan kapasitas parkir optimal adalah 206 SRP dengan durasi parkir 120 menit untuk roda empat dan 306 SRP dengan durasi 180 menit untuk roda dua.

\section{METODE PENELITIAN}

Menurut Wikrama (2010), metode penelitian merupakan suatu metode yang digunakan dalam melaksanakan penelitian yang mencakup langkahlangkah pelaksanaan penelitian dari awal sampai akhir. Sebelum melaksanakan penelitian lebih lanjut, terlebih dahulu harus dipahami tujuan dari penelitian yang dilakukan dan menentukan langkah-langkah yang diambil dalam melaksanakan penelitian tersebut guna memperoleh hasil yang diinginkan. Semua langkahlangkah yang diambil dalam melaksanakan penelitian harus dilandaskan pada diagram alir penelitian yang telah dibuat agar semua langkahlangkah penelitian tersebut tidak menyimpang dari tujuan yang diinginkan (Wikrama, 2010). Berikut ini adalah diagram alir penelitian yang menjadi pedoman dalam melaksanakan penelitian yang dapat dilihat pada Gambar 3.

\section{Lokasi penelitian}

Adapun penelitian ini dilakukan di Bandara Tjilik Riwut Palangka Raya.

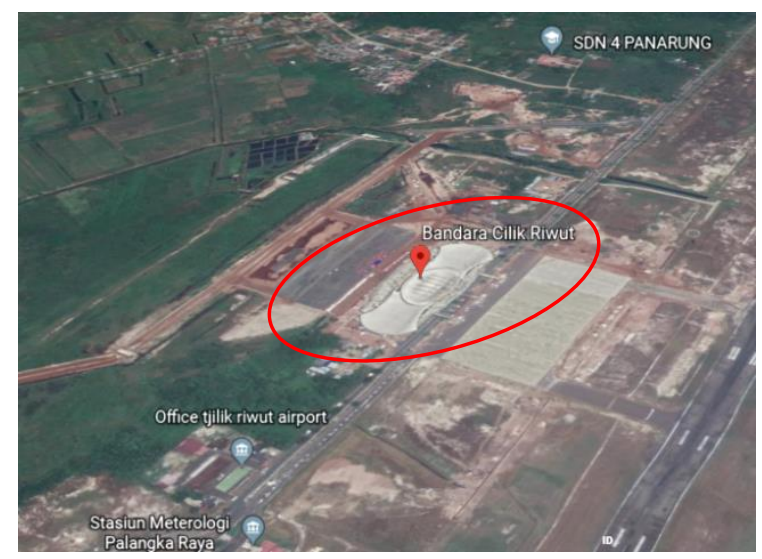

Gambar 2. Lokasi penelitian 


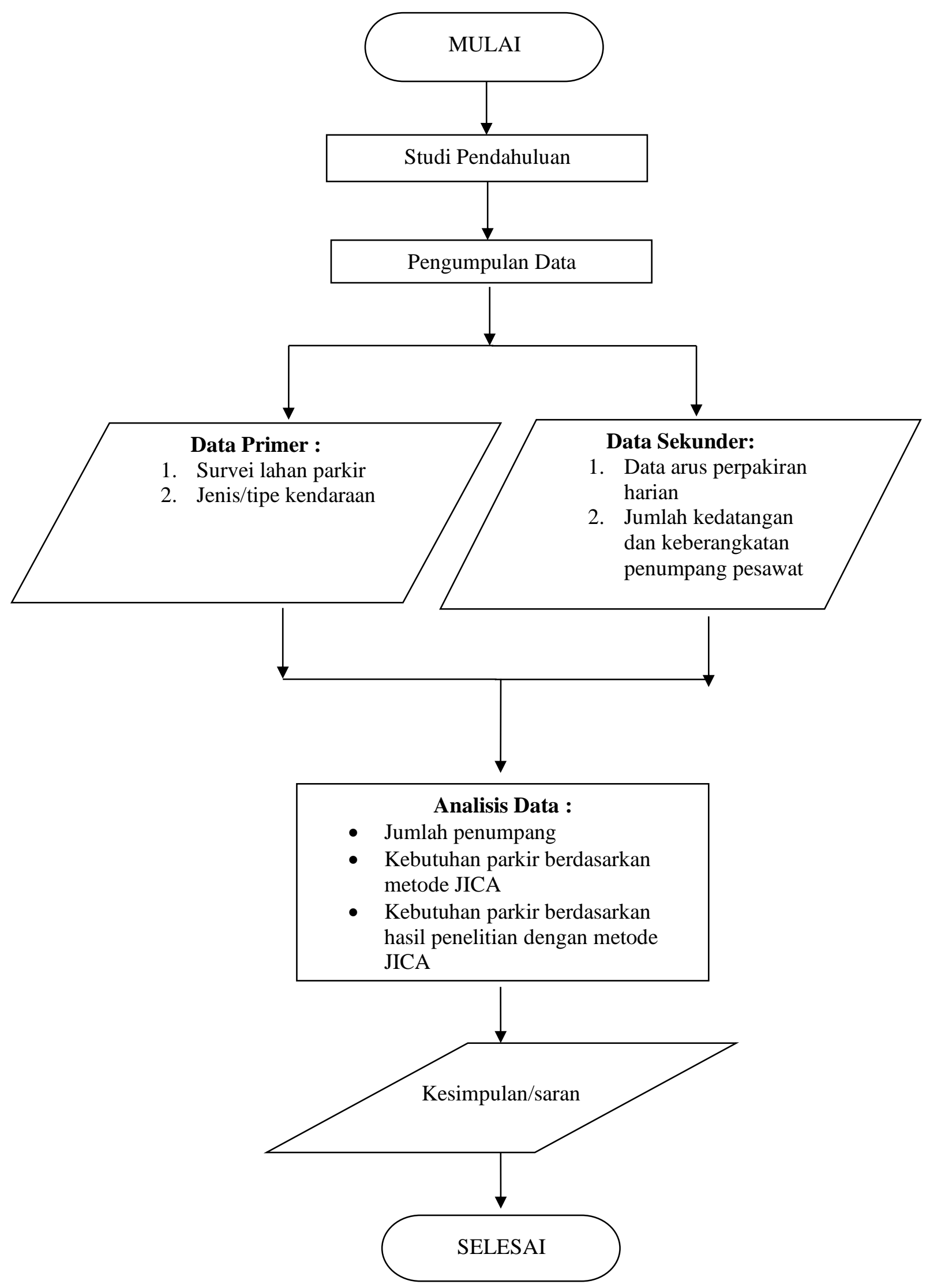

Gambar 3. Bagan alir penelitian 


\section{Tahapan penelitian}

Dalam tahapan penelitian ini diuraikan tahapantahapan yang dilakukan dalam penelitian.

\section{Studi Pendahuluan}

Pada tahapan ini dilakukan studi pendahuluan tentang lokasi dan masalah yang akan dijadikan bahan penelitian dengan melakukan langkahlangkah sebagai berikut :

a) Survei lokasi

Pada tahap ini dilakukan pra survei ke lokasi yang akan dijadikan sebagai objek penelitian yang dimaksudkan untuk mengetahui permasalahan - permasalahan yang ada.

b) Penentuan tujuan dan batasan masalah Pada tahap ini dilakukan penentuan tujuan yang akan dicapai pada akhir penelitian dengan memperhatikan judul dan permasalahan yang dipilih.

c) Studi pustaka

Pada tahap ini dilakukan studi pustaka dengan mengumpulkan literatur atau buku-buku yang ada hubungannya dengan judul penelitian yang dipilih kemudian ditelaah isinya untuk dijadikan sebagai bahan tinjauan pustaka.

\section{Pengumpulan Data}

Pada penelitian ini terdiri dari dua jenis pengambilan data yaitu pengambilan data primer dan pengambilan data sekunder.

1) Data Primer

Data primer merupakan data yang diperoleh dari penelitian atau pengamatan langsung di lapangan sesuai dengan kondisi sesungguhnya. Survei data primer dilakukan sebagai berikut :

a. Survei lahan parkir

Informasi ini akan memberikan gambaran mengenai jumlah ruang parkir, ukuran petak parkir, luas areal parkir, jenis parkir, tata cara pengoperasian parkir, tarif parkir, peta makro dan marka parkir yang tersedia.

b. Survei jenis/tipe kendaraan

Mengamati jenis/tipe parkir kendaraan yang tersedia di areal parkir, seperti: parkir untuk bus, mobil, angkutan umum, dan sepeda motor.

2) Data Sekunder

Data sekunder adalah data yang diperoleh berdasarkan sumber yang sudah ada.

a. Data arus perparkiran harian

Data arus perparkiran harian adalah jumlah kendaraan parkir setiap hari. Dalam penelitian ini diambil data arus perparkiran selama tiga bulan terakhir (September November 2019) dari PT Angkasa Pura II (Persero) KC Bandara Tjilik Riwut.

b. Jumlah kedatangan dan keberangkatan penumpang pesawat

Data jumlah keberangkatan dan kedatangan penumpang pesawat diambil selama tiga bulan terakhir (September November 2019) dari PT Angkasa Pura II (Persero) KC Bandara Tjilik Riwut, kemudian dianalis jumlah penumpang puncak berdasarkan data yang ada.

3. Analisis Data

Langkah-langkah yang dilakukan dalam menganalisis data yang diperoleh adalah sebagai berikut :

1) Menganalisis jumlah penumpang pesawat berdasarkan data sekunder untuk mendapatkan jumlah penumpang tertinggi.

2) Menganalisis kebutuhan areal parkir dengan metode JICA (Japan International Cooperation Agency) menggunakan metode langsung dari JICA.

3) Menganalisis kebutuhan areal parkir dengan metode JICA berdasarkan hasil penelitian. Hasil penelitian dalam hal ini berupa hasil analisis jumlah penumpang dan jumlah kendaraan parkir.

Hasil analisis kebutuhan parkir digunakan untuk mengetahui keseimbangan penyediaan parkir di Bandara Tjilik Riwut.

4. Kesimpulan dan Saran

Penarikan kesimpulan berdasarkan data hasil penelitian yang telah dianalisis kemudian memberikan saran-saran yang berhubungan dengan hasil - hasil penelitian.

\section{HASIL DAN PEMBAHASAN}

\section{Hasil penelitian}

Berikut adalah hasil perhitungan kebutuhan parkir berdasarkan metode JICA dan berdasarkan hasil penelitian menggunakan pendekatan metode JICA. Hasil analisis disajikan dalam tabel 1. Kebutuhan Parkir Berdasarkan Metode JICA, dan tabel 2. Kebutuhan Parkir Berdasarkan Hasil Penelitian. 


\section{Kebutuhan areal parkir berdasarkan metode JICA}

Rasio kendaraan per penumpang mengikuti aturan metode JICA yaitu 0,8 diasumsikan untuk ukuran bandara kecil dan menengah. Jumlah penumpang puncak diambil dari data sekunder. Berdasarkan analisis didapatkan jumlah penumpang puncak tertinggi adalah pada hari Minggu dengan jumlah penumpang 498 orang. Berdasarkan perhitungan kebutuhan areal parkir didapatkan hasil rata-rata kebutuhan areal parkir mobil sebesar $13024 \mathrm{~m}^{2}$.

Tabel 1. Kebutuhan areal parkir berdasarkan metode JICA

\begin{tabular}{lcccc}
\hline $\begin{array}{c}\text { Hari } \\
\text { pengamatan }\end{array}$ & $\begin{array}{c}\text { Rasio } \\
\text { kendaraan per } \\
\text { penumpang }\end{array}$ & $\begin{array}{c}\text { Jumlah } \\
\text { penumpang } \\
\text { puncak }\end{array}$ & $\begin{array}{c}\text { Kebutuhan ruang } \\
\text { parkir sebuah } \\
\text { kendaraan }\left(\mathbf{m}^{2}\right)\end{array}$ & $\begin{array}{c}\text { Kebutuhan areal } \\
\text { parkir }\left(\mathbf{m}^{2}\right)\end{array}$ \\
\hline Senin & 0,8 & 469 & 35 & 13132 \\
Selasa & 0,8 & 440 & 35 & 12320 \\
Rabu & 0,8 & 449 & 35 & 12572 \\
Kamis & 0,8 & 433 & 35 & 12124 \\
Jumat & 0,8 & 470 & 35 & 13160 \\
Sabtu & 0,8 & 497 & 35 & 13916 \\
Minggu & 0,8 & 498 & 35 & 13944 \\
Rata-rata & & & & \\
\hline
\end{tabular}

Sumber: Hasil analisis (2020)

\begin{abstract}
Kebutuhan parkir berdasarkan hasil Berdasarkan hasil penelitian, untuk menentukan penelitian rasio kendaraan per penumpang digunakan pendekatan terhadap jumlah kendaraan parkir

Dalam metode JICA ditentukan rasio kendaraan per penumpang adalah 0,8 yang disesuaikan maksimum dan jumlah penumpang pesawat kedatangan dan keberangkatan pada jam puncak.
\end{abstract} dengan kondisi karakteristik suatu bandar udara.

Tabel 2. Kebutuhan parkir berdasarkan hasil penelitian

\begin{tabular}{lcccc}
\hline $\begin{array}{c}\text { Hari } \\
\text { pengamatan }\end{array}$ & $\begin{array}{c}\text { Rasio } \\
\text { kendaraan per } \\
\text { penumpang }\end{array}$ & $\begin{array}{c}\text { Jumlah } \\
\text { penumpang } \\
\text { puncak }\end{array}$ & $\begin{array}{c}\text { Kebutuhan ruang } \\
\text { parkir sebuah } \\
\text { kendaraan }\left(\mathbf{m}^{2}\right)\end{array}$ & $\begin{array}{c}\text { Kebutuhan areal } \\
\text { parkir }\left(\mathbf{m}^{\mathbf{2}}\right)\end{array}$ \\
\hline Senin & 0,25 & 469 & 35 & 4925 \\
Selasa & 0,25 & 440 & 35 & 4104 \\
Rabu & 0,25 & 449 & 35 & 3850 \\
Kamis & 0,25 & 433 & 35 & 3929 \\
Jumat & 0,25 & 470 & 35 & 3789 \\
Sabtu & 0,25 & 497 & 35 & 4113 \\
Minggu & 0,25 & 498 & 35 & 4349 \\
Rata-rata & & & & \\
\hline
\end{tabular}

Sumber: Hasil analisis (2020)

Keterangan:

Rasio (f)

$=\frac{\text { Jumlah kendaraan parkir maksimum }}{\text { jumlah penumpang pesawat datang dan berangkat }}$

$=\frac{668}{2640}$

$=0,25$
Digunakan data jumlah kendaraan parkir maksimum dan jumlah penumpang berangkat dan datang pada waktu puncak dari PT. Angkasa Pura II (Persero).

Berdasarkan analisis jumlah penumpang pesawat pada jam puncak dan jumlah kendaraan parkir maksimum, maka dapat diketahui rasio kendaraan per penumpang. Selanjutnya rasio tersebut dapat 
digunakan untuk mengetahui kebutuhan areal parkir. Berdasarkan perhitungan didapat jumlah kebutuhan areal parkir rata-rata sebesar $4070 \mathrm{~m}^{2}$. Jika ditinjau dari ketersediaan luasan parkir eksisting yaitu sebesar $4290 \mathrm{~m}^{2}$, maka luasan areal parkir masih mencukupi untuk kondisi saat ini.

\section{Pembahasan}

Berdasarkan kondisi eksisting areal parkir mobil di Bandara Tjilik Riwut memiliki luas sebesar $4290 \mathrm{~m}^{2}$ dengan jumlah petak parkir sebanyak 199 petak. Parkir kendaraan penumpang dan parkir kendaraan pegawai menjadi satu tempat yang sama/ tidak terpisah. Untuk parkir kendaraan roda empat memiliki konfigurasi sudut $45^{\circ}$.

Berdasarkan perhitungan kebutuhan areal parkir dengan metode JICA didapatkan jumlah kebutuhan areal parkir adalah $13024 \mathrm{~m}^{2}$, sedangkan ketersedian luasan parkir yang ada yaitu $4290 \mathrm{~m}^{2}$. Berdasarkan luasan areal parkir tersebut, dapat diketahui bahwa areal parkir mobil memerlukan penambahan luasan parkir sebesar $8734 \mathrm{~m}^{2}$.

Berdasarkan hasil penelitian, didapatkan jumlah kebutuhan parkir sebesar $4070 \mathrm{~m}^{2}$. Ditinjau dari ketersediaan luasan areal parkir yang ada, maka dapat dikatakan bahwa kebutuhan parkir yang ada masih mencukupi untuk kondisi saat ini.

\section{KESIMPULAN DAN SARAN}

\section{Kesimpulan}

1. Berdasarkan hasil perhitungan kebutuhan parkir dengan metode JICA didapatkan ratarata kebutuhan parkir mobil adalah sebesar $13.024 \mathrm{~m}^{2}$. Berdasarkan metode JICA dibutuhkan penambahan areal parkir seluas 8734 $\mathrm{m}^{2}$.

2. Berdasarkan hasil penelitian didapatkan ratarata kebutuhan parkir mobil adalah sebesar $4070 \mathrm{~m}^{2}$. Berdasarkan hasil penelitian dapat dikatakan bahwa luasan areal parkir yang ada masih mencukupi untuk kondisi saat ini.

3. Ditinjau dari kondisi real areal parkir dan hasil penelitian, areal parkir yang ada masih mencukupi untuk kondisi saat ini. Namun untuk pengembangan Bandar udara di masa mendatang, seiring dengan meningkatnya penggunaan sektor transportasi udara, maka dibutuhkan penambahan luas areal parkir untuk memenuhi kebutuhan parkir berdasarkan analisis jumlah penumpang pesawat.

4. Berdasarkan data dan pengamatan pada umumnya kendaraan yang parkir di Bandara Tjilik Riwut bersifat short term atau parkir hanya untuk menaikkan dan menurunkan penumpang (tidak menggunakan areal parkir yang disediakan).

\section{Saran}

Berdasarkan kesimpulan yang diperoleh dari hasil penelitian, terdapat saran-saran dan rekomendasi untuk masukan dan penelitian selanjutnya. Adapun saran-saran tersebut antara lain :

1. Diperlukan penambahan luas areal parkir mobil sebesar $8734 \mathrm{~m}^{2}$ untuk memenuhi kebutuhan parkir berdasarkan perhitungan metode JICA.

2. Untuk pengembangan Bandar udara di masa mendatang, dibutuhkan penambahan luas areal parkir dan manajemen parkir yang optimal untuk memenuhi kebutuhan parkir kendaraan.

3. Perlu diadakan penelitian lebih lanjut untuk perencanaan kebutuhan ruang parkir kendaraan menginap (parkir inap) pada Bandara Tjilik Riwut, karena belum ada tempat parkir khusus untuk kendaraan yang menginap.

4. Sebaiknya disediakan/ditempatkan petugas parkir disetiap lokasi parkir untuk membantu merapikan kendaraan yang parkir sehingga penyediaan tempat parkir menjadi lebih efektif.

\section{UCAPAN TERIMA KASIH}

Ucapan terima kasih disampaikan kepada semua pihak yang telah membantu dan memberikan dukungan dalam penelitian ini. Penulis menyampaikan ucapan terima kasih kepada :

1. Kementerian Pendidikan dan Kebudayaan yang telah memberikan bantuan finansial melalui Beasiswa Bidik Misi tahun 2016 2020 sehingga dapat menyelesaikan pendidikan pada program studi Teknik Sipil Universitas Palangka Raya.

2. PT. Angkasa Pura II (Persero) KC Bandara Tjilik Riwut yang telah memberikan data dan membantu dalam proses penelitian.

3. Dosen pembimbing yang telah membimbing dan mendukung penuh dalam proses penelitian. 


\section{DAFTAR PUSTAKA}

Abubakar, I., (1998). Pedoman Perencanaan dan Pengoperasian Fasilitas Parkir. Direktorat Jendral Perhubungan Darat Bina Sistem Lalu Lintas dan Angkutan Kota, Jakarta.

Azis, Malik, (2017). Analisis Kebutuhan Pelataran Parkir Kendaraan di Bandara Husein Sastranegara Bandung untuk Optimalisasi Ruang Parkir Kendaraan. S1 thesis, Universitas Pendidikan Indonesia, Bandung.

BPS (Badan Pusat Statistik) Kalimantan Tengah, (2019). Provinsi Kalimantan Tengah Dalam Angka. Tercantum dalam website resmi http://kalteng.bps.go.id. Diakses pada 20 September 2019.

Departemen Perhubungan, (1996). Pedoman Teknis Perekayasaan Tempat Perhentian Kendaraan Penumpang Umum. Direktorat Jenderal Perhubungan Darat, Departemen Perhubungan, Jakarta.

Istikhomah, A. N., \& Romadhona, P. J., (2018). Evaluasi Kinerja Fasilitas Parkir Mobil di Bandara Internasional Adisutjipto dan Perkiraan Kebutuhan Parkir Mobil di New Yogyakarta International Airport ( NYIA ). Prosiding Kolokium Program Studi Teknik Sipil (KPSTS) FTSP UII 2018, Juli 2018. Diakses pada 17 November 2019.

JICA, (1992). Airport Terminal Area Planning. Japan International Cooperation Agency (JICA), Civil Aviation Bureau, Ministry of Transport Japan.

Prasetiyo, Timboeleng, \& Poli, (2014). Analisis Kebutuhan Ruang Parkir pada Kawasan Pusat Perdagangan Kota Tomohon. Sabua: Jurnal Lingkungan Binaan dan Arsitektur, Vol.6, No.3: 333 - 340, November 2014. Diakses pada 10 Juli 2020.

PT. Angkasa Pura II (Persero) Bandar udara Tjilik Riwut, (2019). Total Data Angkutan Udara Penerbangan Domestik PT. Angkasa Pura II (Persero) Bandara Tjilik Riwut Bulan September - November Tahun 2019, Palangka Raya.

PT. Angkasa Pura II (Persero) Bandar udara Tjilik Riwut, (2019). Jumlah Kendaraan Parkir PT. Angkasa Pura II (Persero) Bandara Tjilik Riwut Bulan September - November Tahun 2019, Palangka Raya.

Putri, D. A. P. A. G., Suthanaya, P. A., \& Ariawan, M. A., (2017). Analisis Karakteristik dan
Kebutuhan Parkir di Bandara Internasional I Gusti Ngurah Rai-Bali. Jurnal Spektran, Vol.5, No.2: 155 - 162, Juli 2017. Diakses pada 17 November 2019.

Republik Indonesia, (2019). Peraturan Menteri Perhubungan Nomor PM 39 Tahun 2019 tentang Tatanan Kebandarudaraan Nasional.

Saputra, E., \& Mildawati, R., (2017). Analisa Kebutuhan Ruang Parkir Di Bandar udara Raja Haji Fisabilillah Tanjung Pinang Kepulauan Riau. Jurnal Saintis, Volume 17 No.1: 77-83, April 2017. Diakses pada 17 November 2019.

Sholikhin, R., Mudjanarko, S. W., Sipil, T., Sipil, F. T., Narotama, U., \& Sidoarjo, P. L., (2017). Analisis Karakteristik Parkir di Satuan Ruang Parkir Pasar Larangan Sidoarjo. Teknika: Engineering and Sains Journal, Vol.1, No.2: 145-150, Desember 2017. Diakses pada 16 Oktober 2019.

Tamin, Ofyar Z, (2008). Perencanaan dan Pemodelan Transportasi. Institut Teknologi Bandung, Bandung.

Wikrama, Jaya A.A., (2010). Analisis Karakteristik dan Kebutuhan Parkir di Pasar Kreneng. Jurnal Ilmiah Teknik Sipil, Vol. 14, No 2: 158-170, Juli 2010. Diakses pada 14 Agustus 2020. 